\title{
Chaotic shop-talk or efficient parliament? The Reichstag, the parties, and the problem of governmental instability in the Weimar Republic
}

\author{
Sibylle H. Lehmann
}

Received: 5 September 2008 / Accepted: 28 August 2009 / Published online: 19 September 2009

(c) The Author(s) 2009. This article is published with open access at Springerlink.com

\begin{abstract}
The German parliament in the Weimar Republic was very instable and governments did not last long. Historical research has tried to determine what caused this instability. Those historical hypotheses are re-examined by studying a completely new dataset covering 489 roll-call-bills in the parliament during the 14 years in question. According to the findings of this study it is very unlikely that it was only the system, its conditions and its actors that caused instability and that the reasons rather have to be found outside parliament.
\end{abstract}

Keywords Median legislator $\cdot$ Public choice $\cdot$ Economic history $\cdot$ Germany $\cdot$ Weimar Republic · Unemployment

\section{Introduction}

\subsection{The problem}

On the European continent, the interwar period was not a good time for democracy: republics were failing virtually everywhere from Spain to Estonia and from Italy to Poland. However, without any doubt the Weimar Republic (1919-1933) is the most famous and most important such case. After all, it was in Germany that the breakdown of democracy brought a regime to power that plunged the world into the most terrible war it had ever seen, that practiced genocide on an industrial scale and that undermined the very fundament of civilization, in a country that had prided itself on being one of the most cultured of Europe. Explaining how the 1933 events could happen has been a major challenge to research ever since.

The present paper analyses one aspect of the weakness of the Weimar Republic: the short life span of its governments. There were five general elections, that is, one every two and a half years, with on average no administration lasting longer than eight months in office. Altogether, the Republic had 18 governments, 14 of which took office before 1930, when the

S.H. Lehmann $(\bowtie)$

MPI Gemeinschaftsgüter, Bonn, Germany

e-mail: lehmann.sibylle@gmail.com 
president decided to dispense with the parliament and to govern by decree, ${ }^{1}$ thus initiating the final phase of the republic's life. The question this study sets out to answer is: why were the Weimar governments so unstable? In fact, there are only two possibilities: either the cause of instability lay within the parliament, the 'Reichstag', or it came from outside. Accordingly, I will investigate whether it was parliamentary weakness and dysfunctionality that caused the frequent changes in government, or whether other factors, not linked to the efficiency of the parliament, are to blame.

This study is based on a total of 489 reported parliamentary roll-call votes from the time between 1920 and 1933. These bills are used as a sample in order to study the behavior of politicians in the parliament of the first German democracy. By studying this new database, which has not been analysed before, it is possible to improve upon the recent historical and political science literature and to increase our knowledge about the Weimar Republic. In particular, we can test a large number of hypotheses advanced in order to explain the lack of political stability from which the Republic suffered.

The rest of the paper is organised as follows: in the next section of the introduction, I discuss what research hitherto has been. This is necessary because all research questions I ask in order to solve the general problem, which is considered in this article, are based on hypotheses advanced in the literature. These hypotheses are tested with the help of my data, which I introduce in the last part of the introduction. Section 2 of this study concerns the analysis. Here, I first introduce a number of core concepts, such as the question of what defines an efficient government and the assumption that parties and party factions in parliament can be treated as unitary actors. Then, I consider the general functionality of the parliament, i.e., questions related to the factors that determined the success of parties and to the formation of coalitions. Finally, I turn to factors that may have weakened parliament from within, thus causing governmental instability, and to potentially disruptive influences from outside. Section 3 concludes and summarises my findings.

\subsection{Previous work and hypotheses}

In order to answer the question of whether the instability of the Weimar Republic was due to factors from inside or outside parliament, it is helpful to begin by considering a number of more general issues. During the lifetime of the Republic, no party ever managed to achieve an absolute majority either in votes during general elections or in seats within parliament. All governments therefore had to be based on coalitions between several parties. Hence, before considering any potentially disruptive influences, I need to analyse the formation of formal and informal coalitions and the factors that were of importance here. In this context, the historical literature is not very helpful. Descriptions of how the government coalitions of the Weimar Republic were set up can, of course, be found in any account of the political history of interwar Germany, but systematic analyses are lacking. Table 1 provides an overview of the different governing coalitions, their power in seats and their duration in days.

While the historical literature is unhelpful, in the political science literature two competing systematic explanations of coalition formation have been advanced. The first approach sees coalitions as primarily driven by the desire to be on the winning side. In this view, any actor can coalesce with any other actor, regardless of the distance between their policy preferences. Baron and Ferejohn (1989), for example, assume that legislators are willing to exchange votes with any other legislator in order to secure their preferred policy outcomes

\footnotetext{
${ }^{1}$ The president had the right to ignore the parliament and rule the country on his own, applying article 48 of the constitution (Kolb 2002, p. 18).
} 
Table 1 Overview of governments

\begin{tabular}{|c|c|c|c|c|}
\hline Day of nomination & Chancellor & Coalition & Share of seats & $\begin{array}{l}\text { Duration } \\
\text { in days }\end{array}$ \\
\hline 2/13/1919 & Scheidemann (SPD) & SPD, Center, DDP & 78.1 & 128 \\
\hline $6 / 21 / 1919$ & Bauer (SPD) & SPD, Center & 60.3 & 279 \\
\hline $3 / 27 / 1920$ & Müller (SPD) & SPD, Center, DDP & 78.1 & 90 \\
\hline $6 / 25 / 1920$ & Fehrenbach (Center) & Center, DVP, DDP & 36.6 & 319 \\
\hline $5 / 10 / 1921$ & Wirth (Center) & SPD, Center, DDP & 44.6 & 561 \\
\hline $11 / 22 / 1922$ & Cuno & Center, DVP, DDP, BVP & 41.2 & 264 \\
\hline $8 / 13 / 1923$ & Stresemann (DVP) & SPD, DDP, Center, DVP & 58.8 & 109 \\
\hline $11 / 30 / 1923$ & Marx (Center) & DVP, Center, DDP & 36.6 & 185 \\
\hline 06/03/1924 & Marx (Center) & Center, DVP, DDP & 29.2 & 226 \\
\hline \multirow[t]{2}{*}{$01 / 15 / 1925$} & Luther & Center, DVP, DDP, BVP, & & \\
\hline & & DNVP & 55.5 & 370 \\
\hline 01/20/1926 & Luther & Center, DDP, DVP, BVP & 34.7 & 115 \\
\hline 05/16/1926 & Marx (Center) & Center, DVP, DDP, BVP & 34.7 & 258 \\
\hline $01 / 29 / 1927$ & Marx (Center) & Center, BVP, DVP, DNVP & 49.1 & 515 \\
\hline \multirow[t]{2}{*}{$06 / 28 / 1928$} & Müller (SPD) & SPD, Center, BVP, DDP, & & \\
\hline & & DVP & 61.5 & 581 \\
\hline 03/30/1930 & Brüning (Center) & Presidential & & 558 \\
\hline $10 / 09 / 1931$ & Brüning (Center) & Presidential & & 235 \\
\hline 01/06/1932 & v. Papen (Center) & Presidential & & 186 \\
\hline $12 / 04 / 1932$ & v. Schleicher & Presidential & & 58 \\
\hline $01 / 30 / 1933$ & Hitler (NSDAP) & NSDAP, DNVP & 42.5 & \\
\hline
\end{tabular}

Source: (Falter et al. 1986). KPD = German Communist Party; USPD = Independent Social Democrats; $\mathrm{SPD}=$ Social Democrats; DDP = German Democratic Party; Center = Center Party; BVP = Bavarian People's Party; DVP = German People's Party; DNVP = German Nationalist People's Party; NSDAP = National Socialists

on the issues they care about most. Also, if a party is decisive in turning a losing coalition into a winning one, it can demand a high price for participating in this coalition. Hence, the more likely it is that an actor is pivotal, the more power this actor will have in coalition bargaining. In the context of the parliament of the Weimar Republic, this approach predicts that relative party group size, rather than the party groups' policy preferences, is the main determinant of coalition formation. Since I will investigate only the informal coalition formation between two parties and two parties never managed to reach the majority alone, group size can be ignored as a determinant of the probability that tow parts vote together.

By contrast, the second approach assumes that policy preferences drive coalition formation between two parties. In this view, a legislator is more likely to vote with someone whose preference is closer to his own than with someone further away (Axelrod 1970). The theory thus suggests that in explaining coalition formation in Weimar Germany, we need to look at measures of ideological distance between party groups as well as measures of the size of groups forming the coalition. The data set used here allows me to test both hypotheses, my first research question being therefore whether coalition formation was driven by ideology.

In addition to the problem of coalition formation, there is another issue which I need to consider, i.e., party success pure and simple. One major aspect in this context is how 
the ideological position of a party and its size determines party success. Krehbiel (1991), for instance, emphasises the role of the legislative median ${ }^{2}$ in shaping policy outcomes. In my context, I therefore need to discover the position of this median, and to determine how successful the party that represented the median was in terms of votes taken in parliament. Accordingly, I ask a second research question: was the median legislator really crucially important to shaping policies in the parliament of the Weimar Republic?

Having dealt with these background issues, we can turn to the core problem on which this article is focused, i.e., to the question of whether the Weimar parliament was inherently dysfunctional or whether outside influences caused governmental instability. A number of hypotheses have been advanced in the historical literature. In fact, there is a broad strand of historical research that explains the downfall of democracy in Germany by pointing to what scholars perceived as the weakness of the Republic's parliament. Checking whether the Reichstag really was that inefficient is valuable in itself: after all, this line of research may inadvertently have fallen prey to the anti-democratic propaganda of the 1920s as 1930s, when right-wing polemicists used to disparage the parliament as highly ineffectual, as a 'talking shop' or 'higher-order beer hall'. It was easy to believe the propaganda as Sontheimer points out: "The pages of antidemocratic publications contained much unjust and unfair criticism. However, where this aimed at parliamentarism, the parliamentary hustle and bustle of the Weimar period itself gave it some justification. The parliamentarism of the Weimar Republic was ill; so ill, indeed, that it never recovered from its malady, which had been evident early on, and that eventually it succumbed to this disease" (Sontheimer 1978: p. 149).

As my research takes the hypotheses advanced by historians who argue that the Reichstag was weak and chaotic as a starting point, it is useful to take a closer look at them.

To begin with, Hermens (1951), Falter et al. (1986) and others have suggested that the electoral law was the source of instability in the Weimar Republic, because it allowed a large number of small parties to enter parliament. Given the resulting high levels of fragmentation, it was allegedly very difficult to build a stable majority. The present German constitution reflects this view. Today, a party needs at least $5 \%$ of all votes to enter parliament. This hurdle was introduced to keep the number of parties low and protect the parliament from coalition formation problems caused by too many small parties, such as those that had arisen in the Weimar Republic. It is difficult, however, to demonstrate whether a hypothetical 5\% hurdle would have improved the situation in parliament. Table 2 shows that until the elections in May of 1928 small parties did not hold more than $6 \%$ of the seats altogether.

In the years between 1928 and 1932, small parties had quite a large influence, but then they almost completely disappeared. With the above information in mind, the third question this paper asks is, to what extent did the large number of small parties undermine the governing coalition?

In contrast to the view just discussed, historians such as Fenske (1972), Knütter (1998) and Peukert (1987) argue that the dominance of extremist parties made it impossible to build a stable democratic parliament. The extremist parties in question are the Communists (KPD) on the left side of the spectrum and the German National People's Party (DNVP) and National Socialists (NSDAP) on the right. Allegedly, other parties did not want to cooperate

\footnotetext{
2In this context, the definition 'median' does not refer to the votes of the electorate, but to every voter in the parliament, i.e., to the MPs (therefore 'median legislator'). When the parties are aligned on the left-right continuum, the median legislator is a member of the party whose cumulative proportion in terms of seats that the party won in general elections was more than 0.50 . After every election the median voter is a member of the Center party. Furthermore it is important to note than the turnout for each bill does not change the proportions. The median voter is a member of the Center party in every roll-call vote.
} 
Table 2 Distribution of seats in percent after general elections

\begin{tabular}{|c|c|c|c|c|c|c|c|c|}
\hline Parties & $\begin{array}{l}\text { June } \\
1920\end{array}$ & $\begin{array}{l}\text { May } \\
1924\end{array}$ & $\begin{array}{l}\text { Dec. } \\
1924\end{array}$ & $\begin{array}{l}\text { May } \\
1928\end{array}$ & $\begin{array}{l}\text { Sep. } \\
1930\end{array}$ & $\begin{array}{l}\text { July } \\
1932\end{array}$ & $\begin{array}{l}\text { Nov. } \\
1932\end{array}$ & $\begin{array}{l}\text { March } \\
1933\end{array}$ \\
\hline KPD & 0.80 & 13.10 & 9.10 & 11.00 & 13.30 & 14.60 & 17.30 & 12.50 \\
\hline USPD & 18.30 & & & & & & & \\
\hline SPD & 22.20 & 21.20 & 26.60 & 31.20 & 24.80 & 21.90 & 20.90 & 18.60 \\
\hline DDP & 8.50 & 5.90 & 6.50 & 5.10 & 3.50 & 0.70 & 0.35 & 0.80 \\
\hline Center & 13.90 & 13.80 & 14.00 & 12.40 & 11.80 & 12.30 & 12.10 & 11.40 \\
\hline BVP & 4.60 & 3.40 & 3.90 & 3.50 & 3.30 & 3.60 & 3.45 & 2.80 \\
\hline DVP & 14.20 & 9.50 & 10.30 & 9.20 & 5.20 & 1.20 & 1.90 & 0.30 \\
\hline DNVP & 15.50 & 20.10 & 20.90 & 14.90 & 7.10 & 6.10 & 8.90 & 8.00 \\
\hline NSDAP & & 6.80 & 2.80 & 2.40 & 18.50 & 37.80 & 33.80 & 44.51 \\
\hline Small parties & 1.96 & 6.10 & 5.90 & 10.40 & 12.50 & 1.81 & 1.20 & 1.08 \\
\hline Total & 100.00 & 100.00 & 100.00 & 100.00 & 100.00 & 100.00 & 100.00 & 100.00 \\
\hline
\end{tabular}

Source: (Falter et al. 1986)

with the extremist ones, which were just interested in staying in opposition, from where they could easily sabotage the democratic system. Nevertheless, extremist parties constantly gained seats (see Table 2). The KPD started off with less than 1\% in June 1920 and ended with $12.5 \%$ of seats after the last election. The National Socialists started off with 6.8 and ended with $44.5 \%$ of the seats after the final election in March 1933. Consequently, the fourth question I ask is: to what extent did extremist parties influence the decision-making process in parliament?

While this literature has focused on the parliament and parliamentarians, another line of historical research focuses more on external factors. This strand has a long tradition that goes back to views held by contemporaries. For example, Otto Braun (1949), prime minister of Prussia (1920-1932), claimed in his autobiography that Hitler was able to make his way because of 'Moscow and Versailles'. With 'Moscow' he alluded to the influence of the KPD, which during the 1920s increasingly came under the control of Stalin (he thus anticipated the hypothesis which explains the instability of Weimar with the influence of extremist parties). With 'Versailles' Braun referred to the restrictions imposed by the Treaty of Versailles. According to him, the terms of the treaty made it impossible for the Weimar governments to deal with economic pressures, thus allowing Hitler to mobilise the frustrated population for his party. Ritschl (2002) recently formulated this hypothesis more explicitly. He suggested that politicians had no real chance to build a stable and functioning democracy because they were trapped in a double 'principal-agent' problem. This problem was due to the fact that, like all democracies, that of Weimar was based on the principle that all public authority derives from the people. In democracies, power is to be exercised by the people in elections and plebiscites through special legislative, executive and judicial institutions. In other words: politicians act as the agents of voters. Therefore, politicians, or more precisely the coalitions they form, and the population both are faced with typical principal-agent problems, such as information asymmetries, moral hazard and the self-interest of agents. However, in the Weimar Republic there was one additional important feature: politicians had a second principal, namely the Allies. Of course, the Allies did not select politicians, but they tried to control and influence their decisions. They had a very strong position, because Germany did not capitulate until it was completely unable to continue fighting and had no power left 
to negotiate seriously. Furthermore, at the end of the war there was no powerful neutral party left that was able to control peace negotiations and thereby temper the requirements of the winners. Peace negotiations were just between winners. They provided a statement of requirements that Germany had to accept. ${ }^{3}$ German politicians were not able to fulfil the conflicting demands of both principals. For example, if they paid the reparations in time, they had a very limited budget to finance programs to reduce unemployment in order to satisfy the demand of the population.

Another consideration refers to economic conditions. The Weimar Republic experienced periods of extreme economic turmoil, notably in the early 1920s and during the World Economic Crisis 1929-1933. It is well known that such conditions, in particular unemployment, influenced voting decisions in favour of extremist parties in general election (Stogbauer 2001), and it could be possible that it also had direct effects on voting behavior in the Reichstag between general elections. All these considerations lead me to a fifth and final research question: did external conditions, notably the conflict with the allies and the rise of unemployment, have a significant negative impact on agreement and stability within the parliament?

\subsection{The data}

The data that I am using were taken from the official protocols of the parliament, the 'Reichstagsprotokolle', from 1920 to 1933. It is not possible to calculate exactly how representative the roll-call votes were of all votes, since the total number of votes is not reported separately. I am aware of the problems involved in drawing general conclusions about legislative behavior based on a sample which might not reflect the behavior in all parliamentary debates (Carrubba et al. 2006). However, the reported roll-call votes in the Weimar Republic include all important votes of that period, such as votes on the London Ultimate and the Treaty of Versailles. They also include bills about less important issues, and took place frequently. Thus, from a qualitative point of view, the roll-call bills surely seem to be a representative sample of parliamentary decisions.

The data cover all votes published by name, with the exception of those votes that were held to make sure that enough members of the parliament were present to constitute a quorum. Roll-call votes were held when at least 50 members of the parliament demanded it (otherwise votes were anonymous). The number of members of parliaments varied because it was dependent on the total turnout. In 1919, 421 politicians were in the parliament, whereas in 1933 there were 647 seats. Furthermore, roll-call votes had to concern topics of minimum importance ( $\$ 106$ standing order of the parliament, Geschäftsordnung 1922).

As shown in Table 3, bills can be classified into eight categories, where the 'Enabling Act' (Ermächtigungsgesetz) includes all bills concerning paragraph 48 of the Weimar constitution, with which the president was allowed to make certain decisions without the approval of parliament. These bills were requests for the lifting of the Enabling Act. 'Public Finances' includes bills about fiscal matters; 'Labor' includes all bills concerning labor regulations like unemployment insurance, minimum wages and so forth. 'Tax' covers bills about tax laws, for example property and sales taxes, and 'Trade' includes bills about tariffs and export and import regulations. 'Trust' includes 'votes of no confidence' and 'votes of confidence'. During the 13 years under consideration, 60 bills concerned the relationship between government and parliament, which indicates how insecure and unstable the governments were. 'Versailles' includes all bills concerning the Treaty of Versailles, but also all

\footnotetext{
${ }^{3}$ Moreover, allied politicians also had their principals, that is, their populations, who claimed compensations.
} 
Table 3 Overview of voting topics

Source: calculated by author

\begin{tabular}{lcr}
\hline & Frequency & In percent \\
\hline Enabling Act & 23 & 4.70 \\
Public Finances & 63 & 12.80 \\
Labour & 39 & 7.98 \\
Tax & 54 & 11.00 \\
Trade & 30 & 6.13 \\
Trust & 60 & 12.20 \\
Versailles & 32 & 6.54 \\
Others & 188 & 38.45 \\
Total & 489 & 100.00 \\
\hline
\end{tabular}

subsequent treaties or proposals concerning reparations, such as the Young Plan. 'Others' include all bills that do not fit into any of the other categories.

\section{Analysis}

2.1 Core concepts: government efficiency and party factions as unitary actors

All questions considered in this paper focus on possible forces that might have disturbed the efficiency of government. Thus, in order to answer them, it is necessary to first define government efficiency and then, in a second step, to investigate if and under what conditions the particular forces outlined above had a disturbing effect.

Governments are supposed to lead the parliament and to determine policy. A functioning government is defined as one which wins bills. A 'won' bill is in turn defined as a bill passed by a vote where the majority of the members of the governing coalition voted in line with the result of the vote. For example, if $70 \%$ of the governing coalition voted 'yes' in a vote on introducing law y and altogether more than $50 \%$ of the parliament members voted 'yes' and law ' $y$ ' passes, this would be counted as a 'won bill' for the governing coalition, which indicates a functioning government.

In order to win a bill, the governing coalition needs to behave as homogeneously as possible. A second criterion for a functioning government, therefore, is that there should be agreement within the governing coalition, which can be measured with the following 'Agreement Index' (AI) (Hix et al. 2005):

$$
A I_{i}=\frac{\max \left(Y_{i}, N_{i}, A_{i}\right)-0.5\left[\left(Y_{i}+N_{i}+A_{i}\right)-\max \left(Y_{i}, N_{i}, A_{i}\right)\right]}{\left(Y_{i}+N_{i}+A_{i}\right)}
$$

where $Y_{i}$ denotes the number of 'Yes' votes expressed by the governing coalition on a given vote, ' $N_{i}$ ' the number of 'No' votes and $A_{i}$ the number of 'Abstain' votes. As a result, $A I$ equals one when all members of the coalition vote together, and zero when the members of a party are equally distributed among all three of these voting options.

Table 4 provides the agreement index and the percentage share of won votes for the governing coalitions over time. Given the strong positive correlation between the importance of a vote and the total turnout, roll-call votes are weighted by turnout. This eliminates the variability of agreement resulting from the varying importance of bills. Coalition coherence 
Table 4 Measures for the "functionality" of the government

\begin{tabular}{|c|c|c|c|c|c|c|c|}
\hline & All & $\begin{array}{l}\text { RT1 } \\
\text { June } \\
\text { 1920- } \\
\text { May } 1924\end{array}$ & $\begin{array}{l}\text { RT2 } \\
\text { June } \\
\text { 1924- } \\
\text { Dec. } 1924\end{array}$ & $\begin{array}{l}\text { RT3 } \\
\text { Jan. } \\
\text { 1924- } \\
\text { May } 1928\end{array}$ & $\begin{array}{l}\text { RT4 } \\
\text { June } \\
\text { 1928- } \\
\text { Sept. } 1930\end{array}$ & $\begin{array}{l}\text { RT5 } \\
\text { Oct. } \\
\text { 1930- } \\
\text { July } 1932\end{array}$ & $\begin{array}{l}\text { RT6 } \\
\text { Aug. } \\
\text { 1932- } \\
\text { Nov. } 1932\end{array}$ \\
\hline $\begin{array}{l}\text { AI } \\
\text { (st. dev. in } \\
\text { parentheses) }\end{array}$ & $\begin{array}{l}0.77 \\
(0.29)\end{array}$ & $\begin{array}{l}0.79 \\
(0.21)\end{array}$ & $\begin{array}{l}0.93 \\
(0.19)\end{array}$ & $\begin{array}{l}0.71 \\
(0.24)\end{array}$ & $\begin{array}{l}0.90 \\
(0.16)\end{array}$ & $\begin{array}{l}0.73 \\
(0.43)\end{array}$ & \\
\hline $\begin{array}{l}\text { Percentage } \\
\text { share of votes } \\
\text { won }\end{array}$ & 0.84 & 0.70 & 1.00 & 0.86 & 0.86 & 0.93 & \\
\hline $\begin{array}{l}\text { Number of } \\
\text { bills }\end{array}$ & 489 & 80 & 11 & 158 & 134 & 99 & 6 \\
\hline
\end{tabular}

Source: Author's calculation. Note: for the sixth Reichstag (Aug.-Nov. 1932), no AI has been calculated because during this legislative period, the President governed by decree

was variable between the different parliamentary periods and was at its lowest in the third period and in the last period before the president took over. The governing coalitions won most of the votes over the entire period-on average $84 \%$ of the roll-call votes. Only in the first parliament was the number of won votes quite low, at $70 \%$.

The analysis of roll-call votes allows not just the observation of party groups, but also of individual voting behavior. The parliament of the Weimar Republic, however, shows a very high degree of party discipline, i.e., very little volatility in individual voting behavior. The term 'Fraktionszwang', which describes the obligation of a party member to vote in accordance with party policy, was coined in that era (Bracher 1984: 73). Table 5 shows the average agreement index, defined above, for each single party, again weighted by turnout as in Table 4. The descriptive statistics show that all parties voted almost completely homogeneously. The Independent Social Democrats (USPD) had the lowest average AI with 89 in total, whereas the Social Democrats (SPD) were the most cohesive party. All parties became increasingly cohesive in the last two parliamentary periods. The 'Fraktionszwang' was strong, and parties can therefore undoubtedly be treated as single actors in the following analysis.

\subsection{Influence of ideology and party position}

As discussed above, there are two competing explanations of inter-party competition and coalition formation. The first approach sees coalition as primarily driven by the desire to be on the winning side. In the context of the parliament of the Weimar Republic, this hypothesis predicts that relative party group size, rather than the party groups' policy preferences, is the main determinant of coalition formation. Since here I focus on informal coalitions between two party pairs, and as two parties in the Weimar Republic never managed to get a majority, the variable size as a driving factor for coalition formation can be ignored. It matters, however, for the formal coalitions which are analysed when I test whether small or extremist parties had an influence on the behavior of the formal coalition, i.e., the government. I therefore test whether or to what extent the size of a group matters for coalition formation. The second approach assumes that policy preferences drive coalition formation. 
Table 5 Measure of homogeneity by AI for all parties

\begin{tabular}{|c|c|c|c|c|c|c|c|}
\hline & All & $\begin{array}{l}\text { RT1 } \\
\text { June } \\
\text { 1920- } \\
\text { May } 1924\end{array}$ & $\begin{array}{l}\text { RT2 } \\
\text { June } \\
\text { 1924- } \\
\text { Dec. } 1924\end{array}$ & $\begin{array}{l}\text { RT3 } \\
\text { Jan. } \\
\text { 1924- } \\
\text { May } 1928\end{array}$ & $\begin{array}{l}\text { RT4 } \\
\text { June } \\
\text { 1928- } \\
\text { Sept. } 1930\end{array}$ & $\begin{array}{l}\text { RT5 } \\
\text { Oct. } \\
\text { 1930- } \\
\text { July } 1932\end{array}$ & $\begin{array}{l}\text { RT6 } \\
\text { Aug. } \\
\text { 1932- } \\
\text { Nov. } 1932\end{array}$ \\
\hline KPD & $\begin{array}{l}0.97 \\
(0.07)\end{array}$ & & $\begin{array}{l}0.96 \\
(0.018)\end{array}$ & $\begin{array}{l}0.944 \\
(0.10)\end{array}$ & $\begin{array}{l}1 \\
(0)\end{array}$ & $\begin{array}{l}0.99 \\
(0.05)\end{array}$ & $\begin{array}{l}1 \\
(0)\end{array}$ \\
\hline USPD & $\begin{array}{l}0.89 \\
(0.18)\end{array}$ & $\begin{array}{l}0.89 \\
(0.18)\end{array}$ & & & & & \\
\hline SPD & $\begin{array}{l}0.99 \\
(0.27)\end{array}$ & $\begin{array}{l}0.99 \\
(0.018)\end{array}$ & $\begin{array}{l}0.99 \\
(0.009)\end{array}$ & $\begin{array}{l}0.97 \\
(0.042)\end{array}$ & $\begin{array}{l}0.99 \\
(0.001)\end{array}$ & $\begin{array}{l}0.99 \\
(0.01)\end{array}$ & $\begin{array}{l}0.99 \\
(0.005)\end{array}$ \\
\hline DDP & $\begin{array}{l}0.90 \\
(0.17)\end{array}$ & $\begin{array}{l}0.89 \\
(0.18)\end{array}$ & $\begin{array}{l}0.97 \\
(0.057)\end{array}$ & $\begin{array}{l}0.86 \\
(0.19)\end{array}$ & $\begin{array}{l}0.96 \\
(0.13)\end{array}$ & & \\
\hline Center & $\begin{array}{l}0.94 \\
(0.13)\end{array}$ & $\begin{array}{l}0.94 \\
(0.11)\end{array}$ & & $\begin{array}{l}0.92 \\
(0.14)\end{array}$ & $\begin{array}{l}0.92 \\
(0.166)\end{array}$ & $\begin{array}{l}0.97 \\
(0.11)\end{array}$ & $\begin{array}{l}0.98 \\
(0.038)\end{array}$ \\
\hline BVP & $\begin{array}{l}0.94 \\
(0.13)\end{array}$ & $\begin{array}{l}0.89 \\
(0.18)\end{array}$ & $\begin{array}{l}1 \\
(0)\end{array}$ & $\begin{array}{l}0.94 \\
(0.13)\end{array}$ & $\begin{array}{l}0.93 \\
(0.14)\end{array}$ & $\begin{array}{l}0.98 \\
(0.075)\end{array}$ & $\begin{array}{l}1 \\
(0)\end{array}$ \\
\hline DVP & $\begin{array}{l}0.96 \\
(0.10)\end{array}$ & $\begin{array}{l}0.94 \\
(0.12)\end{array}$ & $\begin{array}{l}0.99 \\
(0.012)\end{array}$ & $\begin{array}{l}0.96 \\
(0.087)\end{array}$ & $\begin{array}{l}0.95 \\
(0.14)\end{array}$ & $\begin{array}{l}0.98 \\
(0.04)\end{array}$ & \\
\hline DNVP & $\begin{array}{l}0.94 \\
(0.12)\end{array}$ & $\begin{array}{l}0.94 \\
(0.11)\end{array}$ & $\begin{array}{l}0.98 \\
(0.007)\end{array}$ & $\begin{array}{l}0.94 \\
(0.09)\end{array}$ & $\begin{array}{l}0.93 \\
(0.17)\end{array}$ & $\begin{array}{l}0.99 \\
(0.009)\end{array}$ & $\begin{array}{l}1 \\
(0)\end{array}$ \\
\hline NSDAP & $\begin{array}{l}0.97 \\
(0.09)\end{array}$ & & $\begin{array}{l}0.99 \\
(0.015)\end{array}$ & $\begin{array}{l}0.93 \\
(0.13)\end{array}$ & $\begin{array}{l}0.99 \\
(0.016)\end{array}$ & $\begin{array}{l}1 \\
(0)\end{array}$ & $\begin{array}{l}1 \\
(0)\end{array}$ \\
\hline $\begin{array}{l}\text { Number of } \\
\text { bills }\end{array}$ & 489 & 80 & 11 & 158 & 134 & 99 & 6 \\
\hline
\end{tabular}

Source: Author's calculation

\begin{tabular}{lllllllll}
\hline KPD & USPD & SPD & DDP & Center & BVP & DVP & DNVP & NSDAP \\
\hline Left & & & & & & & & Right \\
\hline
\end{tabular}

Source: de Swaan (1973)

Fig. 1 Left-right continuum

This theory suggests that we need to look at measures of ideological distance between party groups, as well as at measures of the size of groups forming the coalition.

Ideological closeness is defined as closeness on the left-right continuum introduced below. The political scientist de Swaan (1973) provides such a continuum for Germany (Fig. 1), which is consistent with Downs's (1957) model.

The political science literature provides many other methodological approaches to estimating party positions. Methods range from Laver and Garry's (2000) 'computerized content analysis' approach over the 'party-manifesto-based approach' by Budge et al. (2001) and the Comparative Manifesto Project (CMP) to the 'expert survey analysis' by Benoit and Laver (2006). However, these techniques require a sufficient number of party manifestos for 
Table 6 Coalitions: proportion of times the party groups voted together

\begin{tabular}{|c|c|c|c|c|c|c|c|c|c|}
\hline & \multicolumn{2}{|c|}{ Left wing } & \multicolumn{4}{|c|}{ Left-right continuum } & \multicolumn{3}{|c|}{ Right wing } \\
\hline & KPD & $\overline{\text { USPD }}$ & SPD & DDP & Center & $\mathrm{BVP}$ & $\overline{D V P}$ & DNVP & NSDAP \\
\hline \multicolumn{10}{|c|}{ Reichstag 1 (RT1 80 bills) } \\
\hline USPD & & & 0.77 & 0.40 & 0.37 & 0.33 & 0.33 & 0.22 & \\
\hline SPD & & & & 0.47 & 0.51 & 0.43 & 0.38 & 0.32 & \\
\hline DDP & & & & & 0.76 & 0.65 & 0.68 & 0.52 & \\
\hline Center & & & & & & 0.71 & 0.70 & 0.53 & \\
\hline BVP & & & & & & & 0.67 & 0.55 & \\
\hline DVP & & & & & & & & 0.65 & \\
\hline \multicolumn{10}{|l|}{ DNVP } \\
\hline \multicolumn{10}{|c|}{ Reichstag 2 (RT2 11 bills) } \\
\hline KPD & & & 0.18 & 0.09 & 0.09 & 0.09 & 0.09 & 0.54 & 0.50 \\
\hline SPD & & & & 0.81 & 0.63 & 0.81 & 0.81 & 0.09 & 0.20 \\
\hline DDP & & & & & 0.81 & 1.00 & 1.00 & 0.27 & 0.40 \\
\hline Center & & & & & & 0.81 & 0.81 & 0.45 & 0.60 \\
\hline BVP & & & & & & & 1.00 & 0.27 & 0.40 \\
\hline DVP & & & & & & & & 0.27 & 0.40 \\
\hline DNVP & & & & & & & & & 0.90 \\
\hline \multicolumn{10}{|c|}{ Reichstag 3 (RT3 158 bills) } \\
\hline KPD & & & 0.83 & 0.59 & 0.14 & 0.17 & 0.97 & 0.17 & 0.60 \\
\hline SPD & & & & 0.70 & 0.26 & 0.24 & 0.20 & 0.14 & 0.54 \\
\hline DDP & & & & & 0.49 & 0.45 & 0.47 & 0.34 & 0.44 \\
\hline Center & & & & & & 0.91 & 0.91 & 0.82 & 0.38 \\
\hline BVP & & & & & & & 0.87 & 0.84 & 0.42 \\
\hline DVP & & & & & & & & 0.87 & 0.40 \\
\hline DNVP & & & & & & & & & 0.47 \\
\hline
\end{tabular}

all parties, preferably over time. Parties of the Weimar Republic did not regularly publish manifestos. For the KPD, for instance, just one official text is available, published in 1930 (Treue 1956). Most of the party propaganda, advertisement and acquisition of voters were oral or pamphlet form.

An alternative approach that does not require the analysis of party programmes infers policy position from the politicians' voting patterns. This method is called NOMINATE. NOMINATE's theoretical grounding lies in the spatial theory of voting, whereby MPs are assumed to have single-peaked preferences over an $n$-dimensional space, which is the task of the NOMINATE method itself to identify. NOMINATE calculates the 'revealed' position of each MP based on an alternating three-step algorithm using roll call votes (Poole and Rosenthal 1985). For this study, the data on roll-call votes are aggregated by party and not by individuals. Expanding the database by looking at the votes of every individual and estimating party positions using the NOMINATE method is left to future research. However, as shown above, individuals voted overwhelmingly in party line and the approach used here captures the most important voting behavior patterns.

Moreover, the left-right continuum I apply to the Weimar Republic is commonly used. De Swaan (1973), for instance, applied the same measure in order to test his coalition theory 
Table 6 (Continued)

\begin{tabular}{|c|c|c|c|c|c|c|c|c|c|}
\hline & \multicolumn{2}{|c|}{ Left wing } & \multicolumn{4}{|c|}{ Left-right continuum } & \multicolumn{3}{|c|}{ Right wing } \\
\hline & KPD & USPD & $\overline{\mathrm{SPD}}$ & DDP & Center & BVP & $\overline{\mathrm{DVP}}$ & DNVP & NSDAP \\
\hline \multicolumn{10}{|c|}{ Reichstag 4 (RT4 134 bills) } \\
\hline KPD & & & 0.40 & 0.14 & 0.12 & 0.15 & 0.11 & 0.41 & 0.74 \\
\hline SPD & & & & 0.68 & 0.64 & 0.52 & 0.61 & 0.15 & 0.24 \\
\hline DDP & & & & & 0.92 & 0.79 & 0.91 & 0.41 & 0.17 \\
\hline Center & & & & & & 0.79 & 0.90 & 0.47 & 0.21 \\
\hline BVP & & & & & & & 0.78 & 0.48 & 0.27 \\
\hline DVP & & & & & & & & 0.47 & 0.20 \\
\hline DNVP & & & & & & & & & 0.62 \\
\hline \multicolumn{10}{|c|}{ Reichstag 5 (RT5 99 bills) } \\
\hline KPD & & & 0.17 & & 0.07 & 0.06 & 0.11 & 0.43 & 0.88 \\
\hline SPD & & & & & 0.82 & 0.80 & 0.74 & 0.14 & 0.11 \\
\hline Center & & & & & & 0.95 & 0.88 & 0.13 & 0.11 \\
\hline BVP & & & & & & & 0.88 & 0.14 & 0.13 \\
\hline DVP & & & & & & & & 0.22 & 0.26 \\
\hline DNVP & & & & & & & & & 0.77 \\
\hline \multicolumn{10}{|c|}{ Reichstag 6 (RT6 bills) } \\
\hline KPD & & & 0.83 & & 0.16 & 0.16 & 0.00 & 0.00 & 0.16 \\
\hline SPD & & & & & 0.33 & 0.33 & 0.00 & 0.16 & 0.33 \\
\hline Center & & & & & & 1.00 & 1.00 & 0.33 & 0.66 \\
\hline BVP & & & & & & & 0.00 & 0.33 & 0.66 \\
\hline DVP & & & & & & & & 0.66 & 0.00 \\
\hline DNVP & & & & & & & & & 0.16 \\
\hline
\end{tabular}

Source: calculated by author

for Germany. Based on this left-right continuum, I test whether political closeness between two parties increased the probability that they voted in the same way.

Table 6 shows the informal coalitions. Political closeness does indeed seem to have influenced voting behavior. Informal coalition patterns followed the left-right dimension for the first Reichstag. For instance it was more likely that the German Democratic Party (DDP) voted with the Center (76\% of all bills) than with the Bavarian People's Party (BVP) (only $65 \%$ of all bills) and so forth. The governing coalition consisting of DDP, Center and DVP voted on average the same way in about $70 \%$ of the bills. The second Reichstag shows some deviation from the simple left-right continuum: Communists were more likely to vote like the extreme right than like the moderate left-wing parties, and other parties to the left of the center were also less likely to vote like the Center than like the DVP and DNVP. The third Reichstag followed the left-right continuum for the center right, but the Communists still voted with the National Socialists. Center, BVP and DVP improved their coalition coherence by now voting similarly in about $90 \%$ of all bills. The fourth and fifth Reichstag again show voting patterns on the left-right dimension for most parties. This voting behavior of extremist parties is not surprising as both the KPD and the National Socialist were primarily interested in destroying democracy. Altogether, descriptive statistics suggest that political closeness mattered for voting decisions, i.e., that political actors were not 'policy- 
Table 7 Variable distance for party pairs

\begin{tabular}{|c|c|c|c|c|c|c|c|c|}
\hline Distance & Party pai & & & & & & & \\
\hline Distance $=1$ & $\begin{array}{l}\text { KPD, } \\
\text { USPD }\end{array}$ & $\begin{array}{l}\text { USPD, } \\
\text { SPD }\end{array}$ & $\begin{array}{l}\text { SPD, } \\
\text { DDP }\end{array}$ & $\begin{array}{l}\text { DDP, } \\
\text { Center }\end{array}$ & $\begin{array}{l}\text { Center, } \\
\text { BVP }\end{array}$ & $\begin{array}{l}\text { BVP, } \\
\text { DVP }\end{array}$ & $\begin{array}{l}\text { DVP, } \\
\text { DNVP }\end{array}$ & $\begin{array}{l}\text { DNVP, } \\
\text { NSDAP }\end{array}$ \\
\hline Distance $=2$ & $\begin{array}{l}\text { KPD, } \\
\text { SPD }\end{array}$ & $\begin{array}{l}\text { USPD, } \\
\text { DDP }\end{array}$ & $\begin{array}{l}\text { SPD, } \\
\text { Center }\end{array}$ & $\begin{array}{l}\text { DDP, } \\
\text { BVP }\end{array}$ & $\begin{array}{l}\text { Center, } \\
\text { DVP }\end{array}$ & $\begin{array}{l}\text { BVP, } \\
\text { DNVP }\end{array}$ & $\begin{array}{l}\text { DVP, } \\
\text { NSDAP }\end{array}$ & \\
\hline Distance $=3$ & $\begin{array}{l}\text { KPD, } \\
\text { DDP }\end{array}$ & $\begin{array}{l}\text { USPD, } \\
\text { Center }\end{array}$ & $\begin{array}{l}\text { SPD, } \\
\text { BVP }\end{array}$ & $\begin{array}{l}\text { DDP, } \\
\text { DVP }\end{array}$ & $\begin{array}{l}\text { Center, } \\
\text { DNVP }\end{array}$ & $\begin{array}{l}\text { BVP, } \\
\text { NSDAP }\end{array}$ & & \\
\hline Distance $=4$ & $\begin{array}{l}\text { KPD, } \\
\text { Center }\end{array}$ & $\begin{array}{l}\text { USPD, } \\
\text { BVP }\end{array}$ & $\begin{array}{l}\text { SPD, } \\
\text { DVP }\end{array}$ & $\begin{array}{l}\text { DDP, } \\
\text { DNVP }\end{array}$ & $\begin{array}{l}\text { Center, } \\
\text { NSDAP }\end{array}$ & & & \\
\hline Distance $=5$ & $\begin{array}{l}\text { KPD, } \\
\text { BVP }\end{array}$ & $\begin{array}{l}\text { USPD, } \\
\text { DVP }\end{array}$ & $\begin{array}{l}\text { SPD, } \\
\text { DNVP }\end{array}$ & $\begin{array}{l}\text { DDP, } \\
\text { NSDAP }\end{array}$ & & & & \\
\hline Distance $=6$ & $\begin{array}{l}\text { KPD, } \\
\text { DVP }\end{array}$ & $\begin{array}{l}\text { USPD, } \\
\text { DNVP }\end{array}$ & $\begin{array}{l}\text { SPD, } \\
\text { NSDAP }\end{array}$ & & & & & \\
\hline Distance $=7$ & $\begin{array}{l}\text { KPD, } \\
\text { DNVP }\end{array}$ & $\begin{array}{l}\text { USPD, } \\
\text { NSDAP }\end{array}$ & & & & & & \\
\hline Distance $=8$ & $\begin{array}{l}\text { KPD, } \\
\text { NSDAP }\end{array}$ & & & & & & & \\
\hline
\end{tabular}

blind'. The closer parties were on the left-right continuum, the more likely they were to vote together.

In order to test the influence of other variables, I use a simple econometric model, first doing a cross-sectional analysis for the whole period and then running the regressions separately for the three different time periods. Ideological closeness is captured by a dependent variable which I term INFORMAL COALITION, and which is the agreement index as described above, calculated for every pair of parties treated as one group. This creates a total of 36 pairs and 17604 observations. Unlike standard ordinary least squares models, the dependent variable is censored on both sides: the lowest value is zero and the highest value is one. It will therefore be estimated applying a simple Tobit model (see Johnston and Dindardo 1997).

For the independent variables, I use an ordinally scaled variable 'Distance' to measure ideological closeness. Distance is equal to one if parties are next to each other on the leftright continuum, equal to 2 if there is another party in between and so forth. Distance, for instance, is equal to one for the party pairs: KPD and USPD, USPD and SPD, SPD and DDP and so forth, which means that those parties are neighbors on the left-right continuum (see Table 7).

To control for the effect of fixed coalition agreements, I include a dummy variable that is equal to one if both parties were in the government (Govdummy). I further include dummies that control for certain topics.

Table 8 shows the regression results for INFORMAL COALITION, which is the agreement index of two party pairs. The first regression includes all bills. Here, the government dummy is positive and significant. Coalition agreements and higher pressure for parties in the government to find suitable solutions made them coalesce with higher probability than parties that were not in the government. However, breaking down the bills into three time periods shows quite a different picture. The first period (regression 2) begins in 1919 and ends in 1923, which were the years when democracy was still developing. The second period, between 1924 and 1929 (regression 3), was a phase of relative stability, and the third period, between 1930 and 1933 (regression 4), saw the decline and fall of the democracy. 
Table 8 Regression results for INFORMAL COALITION (AI_coalition) between party pairs (Tobit model)

(1)

\begin{tabular}{lllll}
\hline Time periods & Whole time period & $1919-1923$ & $1924-1929$ & $1930-1933$ \\
\hline Dependent variable & Agreement coalitions & & & \\
Govdummy $=1$ if party was in the & 0.071 & -0.083 & -0.020 & 0.256 \\
government & $(8.77)^{* *}$ & $(3.19)^{* *}$ & $(2.05)^{*}$ & $(15.03)^{* *}$ \\
Distance & -0.036 & -0.013 & -0.049 & -0.049 \\
& $(18.96)^{* *}$ & $(3.04)^{* *}$ & $(21.42)^{* *}$ & $(11.28)^{* *}$ \\
Enabling Act & 0.074 & 0.089 & & 0.001 \\
& $(4.46)^{* *}$ & $(3.22)^{* *}$ & & $(0.03)$ \\
Public Finances & 0.064 & 0.023 & -0.013 & 0.151 \\
& $(6.25)^{* *}$ & $(0.99)$ & $(0.92)$ & $(7.27)^{* *}$ \\
Labour & -0.082 & -0.161 & -0.049 & \\
Tax & $(6.91)^{* *}$ & $(2.57)^{*}$ & $(4.36)^{* *}$ & \\
Trade & -0.052 & 0.148 & -0.049 & -0.112 \\
& $(5.33)^{* *}$ & $(5.12)^{* *}$ & $(4.49)^{* *}$ & $(4.37)^{* *}$ \\
Trust & 0.028 & -0.005 & 0.035 & 0.008 \\
& $(2.05)^{*}$ & $(0.17)$ & $(1.70)$ & $(0.35)$ \\
Versailles & 0.010 & -0.026 & -0.003 & 0.049 \\
& $(0.92)$ & $(0.90)$ & $(0.22)$ & $(2.09)^{*}$ \\
Constant & -0.060 & -0.099 & -0.008 & -0.124 \\
& $(4.79)^{* *}$ & $(3.29)^{* *}$ & $(0.53)$ & $(4.67)^{* *}$ \\
$R$-squared & 0.973 & 0.876 & 0.992 & 1.020 \\
Observations & $(116.75)^{* *}$ & $(49.83)^{* *}$ & $(96.52)^{* *}$ & $(51.28)^{* *}$ \\
\hline Absolve & 0.055 & 0.018 & 0.078 & 0.14 \\
& 13497 & 2720 & 6732 & 4045 \\
\hline
\end{tabular}

Absolute value of $t$ statistics in parentheses ${ }^{*}$ significant at $5 \%{ }^{* *}$ significant at $1 \%$

The separate analysis of these periods shows that parties, which were in the government between 1919 and 1929, were less likely to agree with each other than parties generally. Controlling for ideological distance, being in government together only had a positive influence on coalition formation in the last three years of the Weimar Republic. In sharp contrast, ideological influence had a strong influence on the probability of parties voting together and this effect was stable across time. The coefficient is highly significant and negative. Thus, the further apart two parties were on the left-right continuum, the less likely it was that they would vote together. Apparently, parties did vote ideologically.

In the next step, I study how successful the parties were and what determined their success. If parties are ordered on the left-right continuum, the median legislator is a member of the Center party, which therefore should win most of the votes. The farther away a party is from the median legislator, the less likely is it expected to have won a vote.

Table 9 provides descriptive statistics, for each parliament, for the percentage share of 'won votes' for all parties. Neither KPD nor NSDAP managed to win more than about $20 \%$ of all votes before the 6th Reichstag, although the Communists often voted like the National Socialists. Over the period as a whole, parties in the middle of the left-right continuum which were also part of the government, such as Center, DDP and BVP, won most bills. 
Table 9 Percentage share of votes won

\begin{tabular}{|c|c|c|c|c|c|c|c|}
\hline & All & $\begin{array}{l}\text { RT1 } \\
\text { June } \\
\text { 1920- } \\
\text { May } 1924\end{array}$ & $\begin{array}{l}\text { RT2 } \\
\text { June } \\
\text { 1924- } \\
\text { Dec. } 1924\end{array}$ & $\begin{array}{l}\text { RT3 } \\
\text { Jan. } \\
\text { 1925- } \\
\text { May } 1928\end{array}$ & $\begin{array}{l}\text { RT4 } \\
\text { June } \\
\text { 1928- } \\
\text { Sept. } 1930\end{array}$ & $\begin{array}{l}\text { RT5 } \\
\text { Oct. } \\
\text { 1930- } \\
\text { July } 1932\end{array}$ & $\begin{array}{l}\text { RT6 } \\
\text { Aug. } \\
\text { 1932- } \\
\text { Nov. } 1932\end{array}$ \\
\hline KPD & 0.15 & & 0.09 & 0.21 & 0.16 & 0.13 & 0.50 \\
\hline USPD & 0.10 & 0.63 & & & & & \\
\hline SPD & 0.64 & 0.81 & 0.82 & 0.32 & 0.71 & 0.89 & 0.67 \\
\hline DDP & 0.55 & 0.64 & 1.00 & 0.51 & 0.93 & & \\
\hline Center & 0.88 & 0.70 & 0.82 & 0.93 & 0.92 & 0.92 & 0.67 \\
\hline BVP & 0.81 & 0.57 & 1.00 & 0.87 & 0.80 & 0.85 & 0.67 \\
\hline DVP & 0.81 & 0.57 & 1.00 & 0.86 & 0.90 & 0.92 & \\
\hline DNVP & 0.50 & 0.48 & 0.27 & 0.82 & 0.43 & 0.86 & 0.17 \\
\hline NS & 0.21 & & 0.36 & 0.38 & 0.22 & 0.13 & 0.67 \\
\hline Small Parties & 0.69 & 0.50 & 0.73 & 0.69 & 0.66 & 0.07 & 0.67 \\
\hline $\begin{array}{l}\text { Governing } \\
\text { Coalition }\end{array}$ & 0.84 & 0.70 & 1.00 & 0.86 & 0.86 & 0.93 & \\
\hline Bills & 489 & 80 & 11 & 158 & 134 & 99 & 6 \\
\hline
\end{tabular}

Source: calculated by author

Table 10 Variable Median

\begin{tabular}{lll}
\hline Median & Parties & \\
\cline { 2 - 3 } & Left & Right \\
\hline Median $=1$ & & Center \\
Median $=2$ & DDP & BVP \\
Median $=3$ & SPD & DVP \\
Median $=4$ & USPD & DNVP \\
Median $=5$ & KPD & NSDAP \\
\hline
\end{tabular}

As said above, the median legislator was a member of the Center Party (see Fig. 1) for all periods, and the Center Party won most bills. Parties won bills more often the closer they were to the Center Party. The KPD and NSDAP, the parties farthest away from the median voter, won the fewest bills. This classical median voter behavior can more or less be observed in all parliamentary periods.

Again, in order to see whether this effect is significant and not caused by unobserved variables, I apply an econometric model. I calculate the variable SUCCESS, which I use as dependent variable in a simple logit regression. ${ }^{4}$ This is a dummy variable which is equal to one if the majority of the party members voted according to the electoral result. The median voter model predicts that distance to the median voter should be negatively related to success. The distance to the median legislator is measured by the ordinally scaled variable 'Median'. Median is equal to one if the party contains the median legislator; equal to 2 if

\footnotetext{
${ }^{4}$ In total, the regression covers 4491 observations (nine parties times 489 bills). 
Table 11 Regression results for SUCCESS as dependent variable

(1)

\begin{tabular}{|c|c|c|c|c|}
\hline Time periods & Whole time period & 1919-1923 & 1924-1929 & $1930-1933$ \\
\hline \multirow[t]{2}{*}{ Dependent variable } & \multicolumn{4}{|l|}{ Logit regression } \\
\hline & \multicolumn{4}{|c|}{ Success $=1$ if the party won the bill } \\
\hline Govdummy $=1$ if party & 0.342 & -0.344 & 0.534 & 0.245 \\
\hline was in the government & $(3.47)^{* *}$ & $(1.47)$ & $(3.89)^{* *}$ & $(1.11)$ \\
\hline \multirow[t]{2}{*}{$\mathrm{Ai}$} & 1.955 & 0.908 & 2.659 & 0.795 \\
\hline & $(5.36)^{* *}$ & $(1.55)$ & $(5.27)^{* *}$ & $(0.61)$ \\
\hline \multirow[t]{2}{*}{ Share of seats } & 0.000 & 0.017 & 0.001 & -0.004 \\
\hline & $(0.17)$ & $(3.64)^{* *}$ & $(0.49)$ & $(2.39)^{*}$ \\
\hline \multirow[t]{2}{*}{ Enabling Act } & 0.306 & 1.155 & & -0.033 \\
\hline & $(1.48)$ & $(2.98)^{* *}$ & & $(0.11)$ \\
\hline \multirow[t]{2}{*}{ Public Finances } & -0.080 & 0.285 & -0.224 & -0.130 \\
\hline & $(0.62)$ & $(1.01)$ & $(1.12)$ & $(0.56)$ \\
\hline \multirow[t]{2}{*}{ Labour } & -0.128 & -0.644 & -0.182 & \\
\hline & $(0.94)$ & $(0.92)$ & $(1.22)$ & \\
\hline \multirow[t]{2}{*}{ Tax } & 0.045 & 0.535 & -0.048 & -0.118 \\
\hline & $(0.33)$ & $(1.57)$ & $(0.29)$ & $(0.36)$ \\
\hline \multirow[t]{2}{*}{ Trade } & 0.074 & 0.036 & 0.188 & -0.058 \\
\hline & $(0.42)$ & $(0.10)$ & $(0.60)$ & $(0.19)$ \\
\hline \multirow[t]{2}{*}{ Trust } & -0.000 & 0.207 & -0.075 & -0.086 \\
\hline & $(0.00)$ & $(0.58)$ & $(0.40)$ & $(0.39)$ \\
\hline \multirow[t]{2}{*}{ Median } & -0.700 & -0.475 & -0.625 & -1.161 \\
\hline & $(17.22)^{* *}$ & $(3.28)^{* *}$ & $(11.74)^{* *}$ & $(10.59)^{* *}$ \\
\hline \multirow[t]{2}{*}{ Constant } & 0.052 & -0.584 & -0.823 & 2.805 \\
\hline & $(0.15)$ & $(1.00)$ & $(1.64)$ & $(2.02)^{*}$ \\
\hline Log pseudo-likelihood & -1878.46 & -353.22 & $-974,29$ & -478.985 \\
\hline Pseudo $R$-squared & 0.16 & 0.042 & 0.16 & 0.31 \\
\hline \multicolumn{5}{|l|}{ (Mc Fadden) } \\
\hline Wald $\chi^{2}$ & 565.49 & 29.04 & 307.76 & 266.98 \\
\hline Observations & 3403 & 560 & 1764 & 1079 \\
\hline
\end{tabular}

Robust $z$ statistics in parentheses * significant at $5 \%$ ** significant at $1 \%$

the party is the next party on the left-right continuum and so forth. Table 10 provides an overview of the variable 'Median'.

I further include a control variable that is equal to one if the party was a part of the governing coalition (Govdummy). Other exogenous variables are the total agreement index for the parliament as a whole, the number of valid votes, and dummies that control for different topics discussed in parliament.

Table 11 shows the results. Again, the first regression includes all bills, regression 2 the bills between 1919 and 1923, regression 3 the years 1924 to 1929 and regression 4 the years 
between 1930 and 1933. Generally, the government dummy is positive and significant if all bills are considered. It seems that coalition agreements and higher pressure for parties in the government to find suitable solutions mattered for winning a bill. However, this overall effect is created by the success of the government in the years of relative stability between 1924 and 1929. The agreement index for the parties has a positive, and most of the time significant, coefficient. The more coherently a party voted, the more likely it was to win a vote. The share of seats is positive and significant for the time period between 1919 and 1923 and becomes negative after. The more seats a party had, the more likely it was to win votes. The negative impact on the likelihood of winning a vote in the last period can be explained by the extremist parties. They held a large share of seats at the end of the Republic but did not win many votes. It seems, however, that rather than the size of a party, its position on the left-right continuum counted in order to win bills. By contrast, the variable for the distance to the median legislator, 'median', is negative and highly significant for all periods. The closer a party was to the Center Party, of which the median legislator was a member, the more likely it was to win a vote.

\subsection{The impact of small and extremist parties and external factors}

As discussed above, previous research has often emphasised the particular role of the large number of small and extremist parties. The opportunity of a party to harm governmental decisions depends on its relative size compared to the government. The larger the relative size of a party or party group, the more influence they have in votes, provided that all politicians or parties in a certain party group want the same outcome of a bill.

Table 5 provides the agreement index for all extremist parties (KPD, DNVP and NSDAP) separately. All three extremist parties were very coherent. For the National Socialists, we can observe an interesting development. They started quite cohesively in the second parliament, but cohesion decreased after Hitler was arrested for his attempted coup in November 1923 and the National Socialists were officially outlawed. The parliamentary members now changed the name of the party to 'NS liberty movement' and stayed in parliament in almost the same formation. Hitler was granted early release from prison in 1925, but was not allowed to speak in public until 1928. After 1928 the party regained its high degree of cohesion. Losing their popular 'Führer' as representative of the whole party seriously harmed the National Socialists, and this can be seen in the behavior of their MPs. When Hitler could comply with all formalities of a party leader again, he brought the party back to its former strength.

Table 12 provides some further information on small and extremist party groups. All extremist parties treated together as one group also show quite a high level of cohesion, and they even manage to increase this cohesion over the years. Only in the last period cohesion is low, because now the left-wing and right-wing extremists stopped working together against the government. Small parties treated as one group have a relatively low agreement, which shows they lacked common interest and voted independently of each other.

So far it seems that the influence at least of the extremist parties might have been strong, since they were quite coherent and even gained more coherence, while they also gained more seats. In order to determine whether the increased power of extremist parties harmed the government and to test whether small parties had a negative impact on the success of the government, I again apply a simple econometric model. Here, I also control for external factors such as unemployment.

I calculated the following two dependent variables. 
Table 12 Measure of homogeneity by $A I^{\mathrm{a}}$ for extremist and small parties

\begin{tabular}{llllllll}
\hline & All & RT1 & RT2 & RT3 & RT4 & RT5 & RT6 \\
& & June & June & Jan. & June & Oct. & Aug. \\
& & $\begin{array}{l}1920- \\
\text { May 1924 }\end{array}$ & $\begin{array}{l}1924- \\
\text { Dec. 1924 }\end{array}$ & $\begin{array}{l}\text { 1925- } \\
\text { May 1928 }\end{array}$ & $\begin{array}{l}1928- \\
\text { Sept. 1930 }\end{array}$ & $\begin{array}{l}\text { July 1930- } \\
1932-\end{array}$ & Nov. 1932 \\
\hline Small parties & 0.74 & 0.54 & 0.74 & 0.66 & 0.86 & 0.85 & 0.75 \\
& $(0.23)$ & $(0.21)$ & $(0.13)$ & $(0.18)$ & $(0.19)$ & $(0.19)$ & $(0.27)$ \\
Extremist parties & 0.876 & & 0.68 & 0.80 & 0.92 & 0.95 & 0.60 \\
& $(0.18)$ & & $(0.27)$ & $(0.19)$ & $(0.11)$ & $(0.16)$ & $(0.19)$ \\
Number of bills & 489 & 80 & 11 & 158 & 134 & 99 & 6 \\
\hline
\end{tabular}

Source: author's calculation

${ }^{\mathrm{a}}$ The reported values are the average Agreement indices for different parties and party groups for each parliamentary period and for all periods together. Given the strong positive correlation between the importance of a vote and the total turnout, roll-call votes are weighted by turnout. The sample standard deviations are reported in parenthesis

(1) GOVCOHESION, which is the agreement index for the governing coalition (see Table 4). As this variable takes values between 0 and 1 , it is censored on both sides, and I investigate the determinants of this variable using a Tobit model.

(2) GOVSUCCESS, which is a dummy variable that is equal to one if the majority of the governing coalition's vote matches the electoral result (see Table 4). I estimate the determinants of this variable using a simple logistic regression.

When exploring the determinants of these variables, I use the share of seats of extremist parties, the share of seats of small parties, and the agreement indices for both groups as indicators of the strength of the parties. I further include the number of valid votes to account for the general importance of the bills, assuming that the general turnout is higher if the bill is important, and the agreement index for the whole parliament as a proxy for general atmosphere of agreement in the parliament as independent variables.

Table 13 shows the regression results for GOVCOHESION. Again, the first regression includes all bills. Regression 2 covers bills from the years between 1919 and 1923, regression 3 the years 1924 to 1929 and regression 4 the years between 1930 and 1933 . The shares of seats of extremist and small parties seem to have had a positive influence on government cohesion, save in the last period when the coefficients turn negative (though being significant only in the case of small parties).

The agreement indices for both groups also had a positive influence on the coherence of the governing coalition. It seems that neither small parties nor extremist ones disturbed the functionality of the governing coalition. Unemployment, however, did have a negative impact in the time period between 1924 and 1929. This result is actually counter-intuitive, as these were the years of relative prosperity and economic calm, when unemployment was low compared to what came later. Bills about the Treaty of Versailles and related issues have a negative coefficient but did not significantly influence the agreement of the governing coalition in a negative way. Furthermore the coalition was more cohesive when it came to bills about public finances in the years between 1924 and 1929, which were debates about how to finance the reparations and how to consolidate the household. To summarise, before 1930 neither extremist nor small parties disturbed government cohesion. External factors, 
Table 13 Regression results for GOVCOHESION

(1)

\begin{tabular}{|c|c|c|c|c|}
\hline Time periods & Whole time period & 1919-1923 & 1924-1929 & $1930-1933$ \\
\hline Dependent variable & \multicolumn{4}{|c|}{ GOVCOHESION $=A I$ Governing Coalition } \\
\hline Shareothers & $\begin{array}{l}0.899 \\
(1.18)\end{array}$ & $\begin{array}{l}3.987 \\
(0.86)\end{array}$ & $\begin{array}{l}2.410 \\
(2.31)^{*}\end{array}$ & $\begin{array}{l}-2.855 \\
(2.02)^{*}\end{array}$ \\
\hline Shareextreme & $\begin{array}{l}1.620 \\
(3.81)^{\text {** }}\end{array}$ & & $\begin{array}{l}2.740 \\
(4.86)^{\text {*** }}\end{array}$ & $\begin{array}{l}-0.158 \\
(0.15)\end{array}$ \\
\hline ai_extreme & $\begin{array}{l}0.236 \\
(2.63)^{* * *}\end{array}$ & & $\begin{array}{l}0.097 \\
(1.10)\end{array}$ & $\begin{array}{l}0.276 \\
(1.06)\end{array}$ \\
\hline ai_others & $\begin{array}{l}0.206 \\
(2.94)^{* *}\end{array}$ & $\begin{array}{l}-0.017 \\
(0.10)\end{array}$ & $\begin{array}{l}0.031 \\
(0.38)\end{array}$ & $\begin{array}{l}0.324 \\
(2.04)^{*}\end{array}$ \\
\hline ai_all & $\begin{array}{l}0.686 \\
(6.90)^{\text {** }}\end{array}$ & $\begin{array}{l}0.430 \\
(2.64)^{*}\end{array}$ & $\begin{array}{l}0.843 \\
(7.83)^{\text {*** }}\end{array}$ & $\begin{array}{l}0.643 \\
(2.50)^{*}\end{array}$ \\
\hline Unemployment & $\begin{array}{l}0.002 \\
(0.19)\end{array}$ & $\begin{array}{l}-0.056 \\
(1.14)\end{array}$ & $\begin{array}{l}-0.032 \\
(2.49)^{*}\end{array}$ & $\begin{array}{l}0.045 \\
(1.28)\end{array}$ \\
\hline VV & $\begin{array}{l}0.000 \\
(0.14)\end{array}$ & $\begin{array}{l}0.001 \\
(1.10)\end{array}$ & $\begin{array}{l}-0.001 \\
(1.80)\end{array}$ & $\begin{array}{l}0.001 \\
(1.19)\end{array}$ \\
\hline Enabling act & $\begin{array}{l}0.015 \\
(0.11)\end{array}$ & $\begin{array}{l}0.152 \\
(1.08)\end{array}$ & & $\begin{array}{l}0.240 \\
(1.44)\end{array}$ \\
\hline Public Finances & $\begin{array}{l}0.070 \\
(1.26)\end{array}$ & $\begin{array}{l}-0.052 \\
(0.60)\end{array}$ & $\begin{array}{l}0.178 \\
(3.01)^{\text {** }}\end{array}$ & $\begin{array}{l}-0.066 \\
(0.58)\end{array}$ \\
\hline Labour & $\begin{array}{l}-0.141 \\
(2.84)^{* *}\end{array}$ & & $\begin{array}{l}-0.071 \\
(1.42)\end{array}$ & \\
\hline Tax & $\begin{array}{l}0.080 \\
(1.76)\end{array}$ & $\begin{array}{l}0.096 \\
(0.86)\end{array}$ & $\begin{array}{l}0.019 \\
(0.41)\end{array}$ & $\begin{array}{l}0.247 \\
(1.93)\end{array}$ \\
\hline Trade & $\begin{array}{l}0.077 \\
(1.18)\end{array}$ & $\begin{array}{l}0.079 \\
(0.65)\end{array}$ & $\begin{array}{l}-0.093 \\
(1.13)\end{array}$ & $\begin{array}{l}0.280 \\
(2.48)^{*}\end{array}$ \\
\hline Trust & $\begin{array}{l}0.039 \\
(0.74)\end{array}$ & $\begin{array}{l}-0.035 \\
(0.26)\end{array}$ & $\begin{array}{l}0.001 \\
(0.02)\end{array}$ & $\begin{array}{l}0.224 \\
(1.86)\end{array}$ \\
\hline Versailles & $\begin{array}{l}-0.106 \\
(1.61)\end{array}$ & $\begin{array}{l}-0.172 \\
(1.43)\end{array}$ & $\begin{array}{l}-0.106 \\
(1.35)\end{array}$ & $\begin{array}{l}-0.209 \\
(1.66)\end{array}$ \\
\hline Constant & $\begin{array}{l}-0.075 \\
(0.43)\end{array}$ & $\begin{array}{l}0.290 \\
(0.95)\end{array}$ & $\begin{array}{l}0.259 \\
(1.36)\end{array}$ & $\begin{array}{l}-0.241 \\
(0.39)\end{array}$ \\
\hline$R$-squared & 0.179 & 0.166 & 0.315 & 0.182 \\
\hline Observations & 348 & 77 & 221 & 127 \\
\hline
\end{tabular}

however, such as rising unemployment and negotiations on the Treaty of Versailles seem to be negatively related to government cohesion, even in the years of relative stability, 19241929.

A clearer picture emerges from Table 14. It presents the regression results for the logit model where GOVSUCCESS is the dependent variable. The agreement index for the governing coalition has a positive and significant influence. On bills where the government voted more coherently, the probability of winning was higher. 'Ai_all', the agreement index for 
Table 14 Regression results GOVSUCCESS

(1)

\begin{tabular}{|c|c|c|c|c|}
\hline Time periods & Whole time period & $1919-1923$ & $1924-1929$ & $1930-1933$ \\
\hline Dependent variable & \multicolumn{4}{|c|}{ GOVSUCCESS $=1$ if the governing coalition won the vote } \\
\hline \multirow{2}{*}{ Shareothers } & 2.837 & -30.883 & -8.729 & 38.337 \\
\hline & $(0.40)$ & $(0.63)$ & $(0.54)$ & $(1.41)$ \\
\hline \multirow[t]{2}{*}{ Shareextreme } & 1.011 & & -11.708 & 10.490 \\
\hline & $(0.22)$ & & $(1.39)$ & $(0.57)$ \\
\hline \multirow[t]{2}{*}{ ai_coalitions } & 1.681 & 5.430 & 2.839 & 1.746 \\
\hline & $(2.52)^{*}$ & $(3.52)^{* *}$ & $(2.38)^{*}$ & $(0.73)$ \\
\hline \multirow[t]{2}{*}{ ai_all } & 7.782 & 10.560 & 6.160 & 12.619 \\
\hline & $(4.86)^{* *}$ & $(3.17)^{* *}$ & $(2.45)^{*}$ & $(3.37)^{* *}$ \\
\hline \multirow[t]{2}{*}{ ai_extreme } & 2.341 & & 2.943 & -1.597 \\
\hline & $(2.28)^{*}$ & & $(2.37)^{*}$ & $(0.23)$ \\
\hline \multirow[t]{2}{*}{ ai_others } & -0.953 & -1.161 & 0.090 & -0.943 \\
\hline & $(1.05)$ & $(0.61)$ & $(0.08)$ & $(0.39)$ \\
\hline \multirow{2}{*}{ Unemployment } & -0.205 & -0.738 & -0.064 & -0.822 \\
\hline & (1.59) & $(0.93)$ & $(0.31)$ & $(2.33)^{*}$ \\
\hline \multirow[t]{2}{*}{ Enabling act } & -2.091 & 0.965 & & -8.258 \\
\hline & $(1.67)$ & $(0.49)$ & & $(3.95)^{* *}$ \\
\hline \multirow[t]{2}{*}{ Public Finances } & -0.529 & 0.192 & -0.611 & 0.644 \\
\hline & $(0.81)$ & (0.18) & $(0.74)$ & $(0.41)$ \\
\hline \multirow[t]{2}{*}{ Labour } & -1.052 & & -0.745 & \\
\hline & $(1.81)$ & & $(1.08)$ & \\
\hline \multirow[t]{2}{*}{ Tax } & -0.103 & 1.208 & 0.239 & -1.340 \\
\hline & $(0.15)$ & $(0.67)$ & $(0.32)$ & $(0.60)$ \\
\hline \multirow[t]{2}{*}{ Trade } & 0.133 & -0.549 & & -1.666 \\
\hline & $(0.17)$ & $(0.50)$ & & $(1.24)$ \\
\hline \multirow[t]{2}{*}{ Trust } & -0.483 & 0.945 & -0.451 & \\
\hline & $(0.66)$ & $(0.65)$ & $(0.57)$ & \\
\hline \multirow[t]{2}{*}{ Versailles } & -1.817 & 1.607 & & -5.549 \\
\hline & $(2.50)^{*}$ & $(0.76)$ & & $(3.18)^{* *}$ \\
\hline \multirow[t]{2}{*}{ Total number of votes } & 0.014 & 0.012 & 0.001 & 0.057 \\
\hline & $(2.60)^{* *}$ & $(1.23)$ & $(0.15)$ & $(2.59)^{* *}$ \\
\hline \multirow[t]{2}{*}{ Constant } & -8.301 & -9.238 & -3.323 & -24.910 \\
\hline & $(3.59)^{* *}$ & $(2.21)^{*}$ & $(1.13)$ & $(2.25)^{*}$ \\
\hline Observations & 348 & 77 & 199 & 111 \\
\hline
\end{tabular}

Robust $z$ statistics in parentheses $*$ significant at $5 \%{ }^{* *}$ significant at $1 \%$

(3)

(4)

GOVSUCCESS $=1$ if the governing coalition won the vote

$-30.883$

8.729

38.337

(1.41)

$(0.57)$

1.746

$(0.73)$

12.619

$(3.37)^{*}$

$-1.597$

$0.23)$

(0.39)

$-0.822$

$(3.95)^{\text {** }}$

0.644

$(0.74)$

$-0.745$

(1.08)

0.239

$-1.340$

$-1.666$

(1.24)

$-5.549$

0.057

$(2.59)^{* *}$

$(2.25)^{*}$

111

the parliament as a whole, had a positive influence. In times when the parliament was quite cohesive as a whole the government won most of the votes. The total number of votes is a proxy for the importance of votes, because the turnout was much higher for important votes than for less important ones. Thus the probability of winning a vote increased for more important votes. By contrast, neither the share of seats of small parties nor the share of extremist parties affected the probability of governments winning a vote, which means that neither extremist nor small parties harmed the government as they increased in size.

Over the period as a whole, bills about the Treaty of Versailles were negatively related to the probability of the government winning a bill. This result is driven by the last period. 
Other specific topics had no significant influence on government success. It is also important to note that during the last period unemployment had a negative and significant impact on the success of the government. Thus, increased unemployment not only influenced voting behavior in the districts as Stogbauer (2001) showed, but also the voting behavior among politicians in the parliament.

\section{Conclusions}

Why were the governments of the Weimar Republic so unstable? One line of research suggests that the causes of instability can be found in the political system, the Weimar constitution and the political actors of the day. This research still dominates general public opinion, and the political system of Germany today reflects it as well. But according to this study, this view cannot be confirmed. Indeed it seems the parliament worked quite well:

The parties voted coherently, as the agreement index shows in Table 4. Furthermore, political closeness and distance to the median legislator strongly determined voting behavior and voting success. The closer two parties were on the left-right continuum, the more likely it was that they voted together. This is shown in Table 8, which provides the results of the Tobit regression where the dependent variable is the agreement index between two parties. Furthermore, the closer one party was to the Center party, and thus to the median legislator, the more likely it was that they won their votes (Tables 9, 10).

The argument that the electoral law was a cause of increased instability, as a result of too many parties being able to enter the parliament, seems logical (see Hermens 1951; Falter et al. 1986). Pure proportional representation indeed supports a large number of parties, none of which hold a large share of seats, and forces politicians to build coalitions between three or four parties. It also seems plausible that the more parties participate in the government, the harder it is to find agreement.

This paper concludes that the share of seats held by small parties, as well as their coherence, had an ambiguous effect on government cohesion and even none on the government's ability to win a bill. However, it does not seem that small parties harmed the ability of the government. Thus, they did not really disrupt the political decision-making process and hence, it is very doubtful that a 5\% limit would have changed history.

Extremist parties certainly played an important role, at least in the final days of the Weimar Republic. They gained more seats over time and also increased their cohesiveness, but nevertheless did not manage to turn the power gained through seats into political power before the last parliament. According to Tables 13 and 14, extremist parties did not have a great effect on either government cohesiveness or government success. In both regressions the share of extremist parties and the agreement index of the extremist parties were used as exogenous variables. They rather had a positive influence on the functioning of the government, but were insignificant in most specifications.

External conditions seem to have more influence. Bills about the Treaty of Versailles and related questions harmed the success of the government in the last period between 1930 and 1933. Falter (1986) and Stogbauer (2001) have further shown that there is a strong positive relationship between unemployment in certain constituencies and votes for the National Socialists during general elections. The present study shows that unemployment harmed the efficiency of the Weimar government even in periods between general elections.

Altogether, the parliament was not as dysfunctional and confused as is often suggested. The political process followed certain theoretical patterns such as those predicted by the median voter model. Political positions strongly influenced both voting behavior and coalition formation. The closer parties were to each other ideologically the more likely they were 
to vote together. Indeed, this study is consistent with the view that the main causes of the problems the parliament faced during the Weimar Republic are to be found outside of it.

Acknowledgements This article is a revised version of the second chapter of my Ph.D. dissertation (Trinity College Dublin, 2007). I am very grateful to my graduate advisor, Kevin O'Rourke. I would also like to thank Ken Benoit, Carsten Burhop, Albrecht Ritschl, Chery Schonhardt-Bailey, Kamilah Khathib and an anonymous referee for helpful comments and suggestions.

Open Access This article is distributed under the terms of the Creative Commons Attribution Noncommercial License which permits any noncommercial use, distribution, and reproduction in any medium, provided the original author(s) and source are credited.

\section{References}

Axelrod, R. (1970). Conflict of interest. Chicago: Markham.

Baron, D. P., \& Ferejohn, J. A. (1989). Bargaining in legislatures. American Political Science Review, 83, 1181-1206.

Benoit, K., \& Laver, M. (2006). Party politics in modern democracies. London: Routledge.

Bracher, K. D. (1984). Die Auflösung der Weimarer Republik: Eine Studie zum Problem des Machtverfalls in der Demokratie. Düsseldorf: Königsstein.

Braun, O. (1949). Von Weimar zu Hitler. Hamburg: Hammonia.

Budge, I., et al. (2001). Mapping policy preferences: parties, electors and governments: 1945-1998. Oxford: Oxford University Press.

Carrubba, C. J., Gabel, M., Murrah, L., Clough, R., et al. (2006). Off the record: unrecorded legislative votes, selection bias and roll-call vote analysis. British Journal of Political Science, 36, 691-701.

de Swaan, A. (1973). Coalition theories and cabinet formations: a study of formal theories of coalition formation applied to nine European parliaments after 1918. Amsterdam: Elsevier.

Downs, A. (1957). An economic theory of democracy. New York: Harper \& Row.

Falter, J. W. (1986). Unemployment and the radicalisation of the German electorate 1928-1933: an aggregate data analysis with special emphasis on the rise of national socialism. In P. D. Stachura (Ed.), Unemployment and the great depression in Weimar Germany (pp. 187-208). Basingstoke: Palgrave Macmillan.

Falter, J. W., Lindenberger, T., \& Schumann, S. (1986). Wahlen und Abstimmungen in der Weimarer Republik: Materialien zum Wahlverhalten 1919-1933. Munich: Beck.

Fenske, H. (1972). Wahlrecht und Parteiensystem. Frankfurt: Kühne.

Geschäftsordnung (1922). Geschäftsordnung für den Reichstag: beschlossen am 12.12.1922.-Amtl. Ausg. v. 31.12.1922. Berlin: Sittenfeld.

Hermens, F. A. (1951). Demokratie oder Anarchie? Untersuchungen über die Verhältniswahl. Frankfurt: Metzner.

Hix, S., Noury, A., \& Roland, G. (2005). Power to the parties: cohesion and competition in the European parliament, 1979-2001. British Journal of Political Science, 25, 209-234.

Johnston, J., \& Dindardo, J. (1997). Econometric methods. Singapore: McGraw-Hill.

Knütter, H. H. (1998). Die Weimarer Republik in der Klammer von Rechts- und Linksextremismus. In K. D. Bracher, M. Funke, \& H.-A. Jacobsen (Eds.), Die Weimarer Republik 1918-1933 (pp. 387-406). Bonn: Bundeszentrale für politische Bildung.

Kolb, E. (2002). Die Weimarer Republik. Munich: Oldenbourg.

Krehbiel, K. (1991). Information and legislative organization. Ann Arbor: University of Michigan Press.

Laver, M., \& Garry, J. (2000). Estimating party positions from political texts. American Journal of Political Science, 44, 619-634.

Peukert, D. (1987). Die Weimarer Republik. Frankfurt: Suhrkamp.

Poole, K., \& Rosenthal, H. (1985). A spacial model for legislative roll call analysis. American Journal of Political Science, 29, 357-384. 
Ritschl, A. (2002). Deutschlands Krise und Konjunktur 1924-1934: Binnenkonjunktur, Auslandsverschuldung und Reparationsproblem zwischen Dawes-Plan und Transfersperre. Berlin: Akademie Verlag.

Sontheimer, K. (1978). Antidemokratisches Denken in der Weimarer Republik. Munich: DTV.

Stogbauer, C. (2001). The radicalization of the German electorate: swinging to the right and to the left in the twilight of the Weimar Republic. European Review of Economic History, 5, 251-280.

Treue, W. (Ed.) (1956). Deutsche Parteiprogramme, Quellensammlung zur Kulturgeschichte. Göttingen: Musterschmidt. 